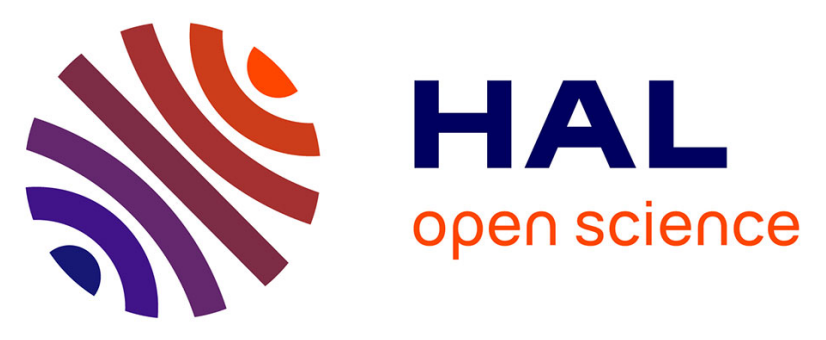

\title{
Quilamine HQ1-44, an iron chelator vectorized toward tumor cells by the polyamine transport system, inhibits HCT116 tumor growth without adverse effect
}

Stéphanie Renaud, Vincent Corcé, Isabelle Cannie, Martine Ropert, Sylvie Lepage, Olivier Loréal, David Deniaud, François Gaboriau

\section{To cite this version:}

Stéphanie Renaud, Vincent Corcé, Isabelle Cannie, Martine Ropert, Sylvie Lepage, et al.. Quilamine HQ1-44, an iron chelator vectorized toward tumor cells by the polyamine transport system, inhibits HCT116 tumor growth without adverse effect. Biochemical Pharmacology, 2015, 96 (3), pp.179-189. 10.1016/j.bcp.2015.06.001 . hal-01163245

HAL Id: hal-01163245

https://hal-univ-rennes1.archives-ouvertes.fr/hal-01163245

Submitted on 19 Nov 2015

HAL is a multi-disciplinary open access archive for the deposit and dissemination of scientific research documents, whether they are published or not. The documents may come from teaching and research institutions in France or abroad, or from public or private research centers.
L'archive ouverte pluridisciplinaire HAL, est destinée au dépôt et à la diffusion de documents scientifiques de niveau recherche, publiés ou non, émanant des établissements d'enseignement et de recherche français ou étrangers, des laboratoires publics ou privés. 
Quilamine HQ1-44, an iron chelator vectorized toward tumor cells by the polyamine transport system, inhibits HCT116 tumor growth without adverse effect.

Stéphanie Renaud, ${ }^{1}$ Vincent Corcé, ${ }^{1,2}$ Isabelle Cannie, ${ }^{1}$ Martine Ropert, ${ }^{3}$ Sylvie Lepage, ${ }^{4}$ Olivier Loréal, ${ }^{1}$ David Deniaud, ${ }^{2}$ and François Gaboriau ${ }^{*}, 1$

${ }^{1}$ INSERM, UMR991, CHRU Pontchaillou, 35033 Rennes, France; Université de Rennes1, 35043 Rennes, France

${ }^{2}$ LUNAM Université, CEISAM, Chimie Et Interdisciplinarité, Synthèse, Analyse, Modélisation, UMR CNRS 6230, UFR des Sciences et des Techniques, 2, rue de la Houssinière, BP 92208, 44322 Nantes Cedex 3, France

${ }^{3}$ Laboratoire de Biologie Générale et Enzymologie, CHRU Pontchaillou, 35033 Rennes, France; Université de Rennes1, 35043 Rennes, France

${ }^{4}$ Laboratoire de toxicologie, CHRU Pontchaillou, 35033 Rennes, France; Université de Rennes1, 35043 Rennes, France

*Corresponding authors:

François Gaboriau, Inserm UMR991, CHRU Pontchaillou, 35033 Rennes, France; Université de Rennes1, 35043 Rennes, France. Phone: 00-33-2-23233861; Fax: 00-33-2-99540137; E-mail: francois.gaboriau@univ-rennes1.fr

Running title: Vectorized iron chelator HQ1-44 inhibits tumor cell growth 
Key words: Iron chelator, iron, polyamine, polyamine transport system, tumor vectorization, cancer, colon adenocarcinoma.

\begin{abstract}
Tumor cell growth requires large iron quantities and the deprivation of this metal induced by synthetic metal chelators is therefore an attractive method for limiting the cancer cell proliferation. The antiproliferative effect of the Quilamine HQ1-44, a new iron chelator vectorized toward tumor cells by a polyamine chain, is related to its high selectivity for the Polyamine Transport System (PTS), allowing its preferential uptake by tumoral cells. The difference in PTS activation between healthy cells and tumor cells enables tumor cells to be targeted, whereas the strong dependence of these cells on iron ensures a secondary targeting. Here, we demonstrated in vitro that HQ1-44 inhibits DNA synthesis and cell proliferation of HCT116 cells by modulating the intracellular metabolism of both iron and polyamines. Moreover, in vivo, in xenografted athymic nude mice, we found that HQ1-44 was as effective as cis-platin in reducing HCT116 tumor growth, without its side effects. Furthermore, as suggested by in vitro data, the depletion in exogenous or endogenous polyamines, known to activate the PTS, dramatically enhanced the antitumor efficiency of HQ1-44. These data support the need for further studies to assess the value of HQ1-44 as an adjuvant treatment in cancer.
\end{abstract}




\section{1- Introduction}

\section{1- Iron metabolism, a new target for anticancer therapy}

Iron is essential in many biological functions and a potential target for anticancer therapy [1]. Initially developed for the treatment of iron overload, iron chelators have shown an antiproliferative action on tumor cells, thus demonstrating their potential value in the treatment of some cancers [2]. Thus, the high efficiency and selectivity of new thiosemicarbazone chelators against various tumors have been reported in vitro and in vivo.[3]. In fact, growing tumor cells require large quantities of iron, leading to an increase in the iron importing proteins and a decrease in the expression of iron exporting proteins [4-6]. In addition, iron exposure stimulates the proliferation of tumor cells in vitro and in vivo [7]. Therefore, decreasing the exchangeable intracellular iron level with synthetic iron chelators appears an attractive method to reduce the proliferation of cancer cells [8]. Our previous results dealing with deferasirox (ICL670), an iron chelator currently used in the treatment of secondary iron overload disease, suggested that its antiproliferative activity results from its inhibitory effects on both iron and polyamine metabolisms [9]. However, these chelators were designed to treat patients exhibiting iron excess. Therefore, their use in patients without iron excess may lead to major side effects, thus limiting their use as antitumoral agents in patients not affected by iron overload. Thus, for potential iron chelators to be used in cancer therapy, they must be vectorized toward tumoral cells.

\section{2- Polyamine, a vector for anticancer agents}

In tumor cells, polyamine metabolism, including biosynthesis and uptake, is particularly amplified [10, 11]. Targeting polyamine metabolism by using polyamine synthesis inhibitors or polyamine catabolism activators was demonstrated to prevent and reduce risk factors associated with the tumor development [12]. The efficiency of the polyamine transport system (PTS) is also greatly increased in tumoral cells. This property is of potential interest for targeting antitumor agents [13-28].

Based on these observations, we have developed a new generation of iron chelators, the Quilamines, in which an 8-hydroxyquinoline chelating subunit is grafted onto polyamine vectors, in order to vectorize the iron chelator inside the cancerous cell with an overactive PTS [29]. The difference in PTS activation 
between healthy and tumor cells enables tumor cells to be targeted whereas the stronger dependence of these latter cells on iron ensures a secondary targeting.

We previously reported that the Quilamine HQ1-44 was highly taken up by the PTS and displayed an efficient antiproliferative activity [29]. As expected during the design of Quilamines, the polyamine chain, involved in the metal coordination, reinforced the affinity for iron (III) and the ferric complex was shown to adopt preferentially a 1:2 [Fe/HQ1-44] stoichiometry at $\mathrm{pH}=7.4$.

We extended the screening of the antiproliferative activity of HQ1-44 to various tumor cell lines and compared it to two non-tumoral cell lines [30]. The relationship between PTS activity and antiproliferative efficiency of HQ1-44 in these various cancer cell lines clearly demonstrated that the Quilamine HQ1-44 was the most efficiently recognized by the active PTS of human colon adenocarcinoma HCT116 cell lines. Consequently, this Quilamine exhibited the higher antiproliferative efficiency on this cell line. In contrast, a low cytostatic effect was observed in normal cells. Colorectal cancer (CRC) is the second most common cause of death from cancer in France and the fourth most commonly diagnosed cancer in the world, so we choose to demonstrate the proof of the Quilamine concept on this kind of cancer.

In the present work, our aim was to investigate the impact of HQ1-44 on cell proliferation and the mechanisms involved as well as assessing its efficiency and tolerance in vivo as an antitumoral treatment in athymic nude mice xenografted with HCT116 cells, by comparison with cis-platin.

\section{2- Materials and Methods}

\section{1- In vitro study}

\subsection{1- Chelator solutions}

All reagents were obtained from Sigma-Aldrich (Saint Quentin Fallavier, France) at the highest available grade. Stock solutions of the Quilamine HQ1-44 (10 $\mathrm{mM})$ were prepared in water. Cells were supplemented with iron by exposure to $20 \mu \mathrm{M}$ exogenous iron-citrate complexes (1:10) for $72 \mathrm{~h}$.

\subsection{2- Cell studies}


The involvement of the PTS in the selective uptake of Quilamine HQ1-44 was investigated in the HCT116 cell line, derived from human colon carcinoma (ATCC number 91091005). We previously demonstrated

the higher sensitivity of this cell line to Quilamines, compared to other carcinoma cells [30].

These cells were grown in McCoy's medium (Life Technologies, Invitrogen ${ }^{\mathrm{TM}}$, Saint Aubin, France), supplemented with 10\% fetal calf serum (Eurobio, Les Ulis, France), 100 units $/ \mathrm{mL}$ penicillin and 50 $\mu \mathrm{g} / \mathrm{mL}$ streptomycin, at $37^{\circ} \mathrm{C}$ in $5 \%$ humidified $\mathrm{CO}_{2}$.

\subsection{3- Cell treatment}

For experiments, cells were harvested with trypsin and seeded $24 \mathrm{~h}$ before the treatments in microplates (Becton Dickinson, Oxnard, CA, USA) at a density of 10,000 cells $/ \mathrm{cm}^{2}$. In these conditions, cells reached confluency in 5-6 days. Chelator exposure was performed one day (D1) or one week (D8) after cell seeding in proliferating or confluent HCT116 cells, respectively. The effect of Quilamine on cell viability was also tested in the presence of DFMO $(1 \mathrm{mM})$, a selective inhibitor of ODC, which induced a depletion of intracellular putrescine and spermidine and thus activated the PTS. In this case, preincubation, in the presence of the ODC inhibitor, was performed prior to the Quilamine treatment. In other experiments, 50 $\mu \mathrm{M}$ of spermidine was added to the culture medium to perform a competitive inhibition of Quilamine uptake through the PTS. Aminoguanidine $(1 \mathrm{mM})$, an inhibitor of the serum amine oxidase, was added to the cell culture medium to prevent the oxidation of exogenous polyamine.

For the caspase 3/7 activity assay, Quilamine uptake quantification, polyamine concentration determination and iron status evaluation, cell lysates were obtained after $72 \mathrm{~h}$ of treatment. After supernatant collection for biochemical analysis, cells were washed twice with $1 \mathrm{~mL}$ of ice-cold phosphatebuffered saline solution (PBS). Cells were collected by scraping in $1 \mathrm{~mL}$ PBS, and then centrifuged for 5 min at 2,000 g. The cell pellet was sonicated for $30 \mathrm{~min}$ at $4^{\circ} \mathrm{C}$ in $500 \mu 1$ of pure water. Protein content in cell extracts was measured according to a method adapted from Bradford (1976) (Bio-Rad Protein Assay, Bio-Rad, Ivry sur Seine, France) and absorbance was read at $595 \mathrm{~nm}$.

\subsection{4- Measurement of cytostatic and cytotoxic effects}

Treatments was performed one day (D1) or one week (D8) after cell seeding in proliferating or confluent HCT116 cells, respectively. After $72 \mathrm{~h}$ of incubation at $37^{\circ} \mathrm{C}$, cell supernatants were collected for 
cytotoxicity evaluation (cytotoxicity detection kit - LDH, Roche, Penzberg, Germany). Results were reported as a percentage of extracellular LDH activity with respect to the control value.

Cell viability was determined by cell nuclei counting after Hoechst 33342 staining and the dose-effect curves were analyzed according to an established procedure [30]. The number of cell nuclei was reported as a percentage of the value obtained in control conditions. Due to their biphasic feature, the dose-response curves were fitted as the sum of two sigmoids (double 4-parameter fit) according to Rodbard [31]. The various parameters, including the percentage and the $\mathrm{IC}_{50}$ values of each sigmoid, were deduced from these fits. Three independent replicates were performed for each experiment, which was repeated three times.

\subsection{5- Measurement of DNA synthesis}

DNA synthesis was assessed by tritiated thymidine incorporation. Twenty-four hours before cell harvesting, $\left[{ }^{3} \mathrm{H}\right]$ methyl-thymidine (Amersham, Uppsala, Sweden) was added to the culture medium at a final concentration of $0.5 \mu \mathrm{Ci} / \mathrm{mL}$. Cells were washed twice with PBS and lysed in $0.1 \mathrm{M} \mathrm{NaOH}$. DNA precipitation was achieved with $30 \%$ trichloroacetic acid (TCA), followed by two washes with $10 \%$ and 5\% TCA successively, and dissolution in formic acid. The radioactivity of $200 \mu \mathrm{l}$ of this formic solution was counted in $5 \mathrm{~mL}$ of Instagel using a Packard Tricarb 2100TR scintillation counter $\beta$ (Perkin Elmer, Waltham, MA, USA) and expressed as cpm/g of protein.

\subsection{6- Analysis of the cell cycle}

The cell cycle was assessed by flow cytometry. Cells were detached with trypsin and nuclei were stained with propidium iodide (Cycletest Plus Kit, Becton Dickinson, Le Pont de Clais, France). Data were acquired and analyzed with a FACSCalibur flow cytometer (Becton Dickinson) using Cell Quest software (Becton Dickinson).

\subsection{7- Measurement of caspase $3 / 7$ activity}

Apoptosis was assessed through caspase 3/7 activity quantification, using the "AMC caspase-3/7 assay" kit (AnaSpec, Fremont, CA, USA), in accordance with the manufacturer's instructions. Caspase 3/7 activity measured by fluorescence at 440/460 nm was expressed as RFU/g of protein and reported as a percentage with respect to untreated control cells. 


\subsection{8- Measurement of gene expression}

Total RNA extracted using "SV total RNA isolation system” kit (Promega, Wisconsin, USA) was tested

by spectrophotometrical dosage and electrophoretic separation on a 1.5\% agarose gel. RNA was reversetranscribed to synthesize cDNA using Moloney Murine Leukemia Virus reverse-transcriptase (Promega, Wisconsin, USA). Gene expression was measured by real-time quantitative PCR performed in triplicate on an ABI Prism 7000 Sequence Detection System (Applied Biosystems, London, UK) using the qPCR Mastermix Plus for SYBR Green I kit and specific primer (Eurogentec, Seraing, Belgium) designed by Primer Express 1.0 software (Table 1). The relative quantification of mRNA levels was calculated after normalization using $18 \mathrm{~S}$ RNA as an endogenous reference. The results were expressed as percentage compared to control culture.

\subsection{9- Measurement of HQ1-44 uptake in HCT116 cells}

HQ1-44 exposure at $1 \mu \mathrm{M}$ was performed one day (D1) or one week (D8) after cell seeding in proliferating or confluent HCT116 cells, respectively. Quilamine uptake was also measured after activation of the PTS ( $1 \mathrm{mM}$ DFMO, see below) or in the presence of $50 \mu \mathrm{M}$ exogenous spermidine in the culture medium to perform a competitive inhibition of the HQ1-44 uptake by the PTS. Cell lysates were ultracentrifuged for $10 \mathrm{~min}$ at 15,000 $\boldsymbol{g}$ and HQ1-44 was quantified in the supernatant by LC/MSMS.

\subsubsection{0- LC/MS quantification of HQ1-44 in HCT116 cells}

Analyses were performed on a liquid chromatograph coupled with an ultra-high-resolution and accurate mass instrument (LC-HR-MS), Q ExactiveTM equipped with an Orbitrap mass analyzer (Thermo Scientific, San Jose, USA). An HESI source was used for the ionization of target compounds. Data acquisition, peak integration and calibration were performed using Xcalibur ${ }^{\circledR} 2.1$ software (Thermo Scientific, San Jose, CA, USA).

LC separation was carried out using a gradient on a C18 Hypersil Gold column (100 mm x 2.1, $3 \mu \mathrm{m})$ from Thermo Scientific (San Jose, USA). The mobile phases used were $10 \mathrm{mM}$ ammonium acetate buffer containing $0.1 \%(\mathrm{v} / \mathrm{v})$ formic acid (solvent A) and methanol/water $(95 / 5, \mathrm{v} / \mathrm{v})$ (solvent B). The mobile phase was delivered at a flow rate of $300 \mu \mathrm{L} / \mathrm{min}$ using the following stepwise gradient elution program: initial conditions of $100 \%$ solvent A maintained for 3 minutes, run from $100 \%$ solvent $\mathrm{B}$ at 2 minutes, 
maintained for 1 minute, run from 100\% solvent A at 1 minute and conditions of $100 \%$ solvent maintained for 5 minutes for equilibration. All prepared samples were kept at $15^{\circ} \mathrm{C}$ in the autosampler until injection of $5 \mu \mathrm{L}$ into the LC-HR-MS system (partial loop) in a thermostated column at $25^{\circ} \mathrm{C}$.

The MS conditions were as follows: HESI in positive mode, capillary temperature: $300^{\circ} \mathrm{C}$; spray voltage: $4500 \mathrm{~V}$; sheath and auxiliary gas (nitrogen) flow-rate: 30 and 15 (arbitrary units), respectively. Data were acquired in full scan mode. Full mass spectra were scanned in the mass range 120 to $700 \mathrm{~m} / \mathrm{z}$, the AGC Target was $1 \mathrm{e}^{6}$ and the resolution was 140,000 (FWHM). The measured accurate $\mathrm{m} / \mathrm{z}$ values of the protonated species was 317.2337. Quantitation was achieved by extracting the exact mass of the protonated species using a 10-ppm extraction window. Quilamine concentrations were then deduced from the calibration curves obtained from HCT116 cell lysate enrichments with various concentrations of HQ144, followed by their sonication and ultrafiltration.

Each HQ1-44 measurement was determined in triplicate and was corrected for protein content in the cell extracts.

\section{2- In vivo study}

\subsection{1- Xenografted nude mice model studies}

All animal experiments were approved by the Rennes Ethics Committee for Animal Experimentation and by the Ministry for Higher Education and Research. Mice were housed in individually ventilated cages in pathogen-free quarters in the animal handling facility of Rennes 1 University (ARCHE-Biosit). The 5week-old athymic female Swiss nude mice (Charles River, Saint Quentin Fallavier, France) were acclimated in a sanitary room for 1 week before the start of the experiments. Viable HCT116 colon cancer cells $\left(3.0 \times 10^{6}\right.$ in medium $\left./ 100 \mu \mathrm{l}\right)$ were injected subcutaneously into the right flank of the nude mice.

\subsection{2- Comparison of antitumoral efficiency of HQ1-44 and cis-platin}

Ten days after tumor cell inoculation, mice showing a tumor volume between $80-120 \mathrm{~mm}^{3}$ were divided randomly into different treatment groups ( 6 mice per group) and were treated daily by intraperitoneal injection of Quilamine HQ1-44 at different doses $\left(0,6.6,20\right.$ and $\left.40 \mathrm{mg} \cdot \mathrm{kg}^{-1}\right)$ or cis-platin (4 mg.kg $\left.{ }^{-1}\right)$ for 17 days. The mice were observed daily. Mice weight and tumor volume were measured three times per 
week with a digital caliper. Tumor volumes were calculated according to the formula for a spheroid: tumor volume $=0.5 \mathrm{x}$ length $\mathrm{x}$ width ${ }^{2}$. Growth inhibition was calculated from the start of treatment by comparing

the change in tumor volume for vehicle and treated groups.

\subsection{3- Effect of activation of PTS on the antitumoral efficiency of HQ1-44}

PTS activation was induced by a nutritional deficiency in polyamine (polyamine deficient chow, PDC) as previously described [32] and/or by inhibition of the polyamine biosynthetic pathway with $\alpha-$ difluoromethylornithine (DFMO, 3\% (w/w) in the drinking water). This activation was associated or not with the Quilamine treatment.

Ten days after tumor cell inoculation, mice showing a tumor volume between $80-120 \mathrm{~mm}^{3}$ were randomly divided into 6 treatment groups (9 mice per group). Mice received PDC supplemented or not with polyamine (21 mg. $\mathrm{kg}^{-1}$ putrescine. $2 \mathrm{HCl}, 153 \mathrm{mg} . \mathrm{kg}^{-1}$ spermidine. $3 \mathrm{HCl}, 48.7 \mathrm{mg} . \mathrm{kg}^{-1}$ spermine. $\left.4 \mathrm{HCl}\right)$ and/or DFMO 3\% (w/w) in their drinking water. Quilamine-treated mice groups were treated daily by intraperitoneal injection of Quilamine HQ1-44 at $40 \mathrm{mg} \cdot \mathrm{kg}^{-1}$ for 17 days. The mice were observed daily. Mice weight and tumor growth were measured three times per week. Growth inhibition was calculated from the start of treatment by comparing the change in tumor volume for vehicle and treated groups.

Mice were sacrificed the day after the last injection. Blood was collected by intra-cardiac puncture after anesthesia. Liver, spleen, heart, kidneys and tumor were collected, weighed, and frozen at $-80^{\circ} \mathrm{C}$ for biochemical and gene expression analyses and/or fixed in formaldehyde for histological analyses.

\subsection{4- Blood analysis}

Whole blood was collected in heparinized microtubes. After collection of the plasma for biochemical analyses (iron, transferrin, ferritin), $100 \mu \mathrm{L}$ of red blood cells (RBC) was discarded for polyamine measurement according to a described method [33] [34]. The LC/MSMS analysis of the dansylated polyamines, adapted from a described method [35, 36], was performed with a Thermo Scientific TSQ Quantum Ultra (Thermo Fisher Scientific, Courtabeuf, France).

Levels of intracellular iron were measured by a colorimetric method using OSR6286 kits (Olympus Diagnostics $\mathrm{GmbH}$, Lismeehan, Ireland) on an Olympus AU 2700 chemistry autoanalyzer (Olympus Diagnostics GmbH, Hamburg, Germany). 
Ferritin and transferrin were quantified in plasma by ELISA using a mouse-specific assay kit in accordance with the manufacturer's recommendations (Mouse Ferritin Elisa Kit, Abnova; Mouse

\section{Transferrin Elisa Kit, Genway).}

\subsection{5- Statistical analysis}

Results from in vitro studies were replicated three times and expressed as means $\pm \mathrm{SD}$. Within the in vivo study, results from each animal group were expressed as means \pm SD. Statistical analysis was performed using the non-parametric Mann-Whitney test. The significance level was set at 0.01.

\section{3- RESULTS}

\section{1- HQ1-44-induced decrease in HCT116 cell growth involves the PTS}

The dose-effect curves obtained after treatment of proliferating HCT116 cells (D1) with HQ1-44, could be deconvoluted into two components (Figure 1A). For Quilamine concentrations lower than $10 \mu \mathrm{M}$, the first component indicated the antiproliferative effect of the Quilamine $\left(62 \%\right.$ of component 1 with $\mathrm{IC}_{50-1}=1$ $\mu \mathrm{M})$. For higher concentrations, the second component reflected the cytotoxic effect (38\% of component 2 with $\mathrm{IC}_{50-2}=165 \mu \mathrm{M}$ ), linked to membrane damage and a release of lactate dehydrogenase (LDH) into the supernatant (Figure 1B). In contrast, when confluent cells, eight days after cell seeding (D8), were treated with HQ1-44, the dose-effect curve was reduced to one component $\left(\mathrm{IC}_{50}=210 \mu \mathrm{M}\right.$, Figure $\left.1 \mathrm{~A}\right)$, associated with LDH release into the supernatant (Figure 1B).

To explore the involvement of the PTS in HQ1-44 vectorization and consequently its antiproliferative effect, we used two approaches. Firstly, PTS activation was induced by a treatment with $\alpha$ difluoromethylornithine, DFMO (1 $\mathrm{mM})$, an inhibitor of ornithine decarboxylase (ODC), leading to polyamine depletion and an increase in PTS expression. This activation improved the antiproliferative effect of HQ1-44 at D1, as shown by the increase in the first component (70\%) and the decrease in the $\mathrm{IC}_{50-1}$ value $(0.5 \mu \mathrm{M})$ (Figure $\left.1 \mathrm{~A}\right)$. In contrast, co-incubation of the HCT116 cells in the presence of $50 \mu \mathrm{M}$ spermidine, a natural polyamine, at D1 led to a competitive inhibition of HQ1-44 uptake by the PTS and thus an inhibition of its antiproliferative effect $\left(60 \%\right.$ of cytostatic component 1 with $\left.\mathrm{IC}_{50-1}=3.5 \mu \mathrm{M}\right)$. 
Secondly, the HQ1-44 uptake measured in cell lysates by LC/MSMS was six-fold higher in proliferating (D1) than in confluent (D8) HCT116 cells (Figure 1C), and the activation of the PTS by DFMO treatment

\begin{abstract}
in proliferating cells led to a two-fold increase in Quilamine uptake. In contrast, co-incubation of proliferating cells with exogenous spermidine $(50 \mu \mathrm{M})$ competitively inhibited the Quilamine uptake by the PTS. In confluent cells, both DFMO and spermidine remained ineffective in activating or inhibiting, respectively, the Quilamine uptake.
\end{abstract}

\title{
3.2- HQ1-44 reduces DNA synthesis, stopping the cell cycle and inducing apoptosis
}

HCT116 cells were seeded at a cellular density allowing their analysis in the proliferative phase $(10,000$ cells $/ \mathrm{cm}^{2}$ ). In the untreated control cells, ${ }^{3} \mathrm{H}$-thymidine incorporation, evaluating DNA synthesis, increased with time $24 \mathrm{~h}$ and $48 \mathrm{~h}$ after cell seeding and reached a plateau at $72 \mathrm{~h}$ (Figure 2A). After $72 \mathrm{~h}$, cells reached confluency and DNA synthesis was slowed down. In the HCT116 proliferating cells treated with a concentration of HQ1-44 close to its $\mathrm{IC}_{50-1}$ value $(2 \mu \mathrm{M})$, DNA synthesis was weakly inhibited compared to the control after $48 \mathrm{~h}$ incubation and, to a lesser extent, at $72 \mathrm{~h}$ ( $45 \%$ of inhibition).

Analysis by flow cytometry of the percentage of cells in the various phases of the cell cycle in untreated control cells at different growth times after cell seeding $(24,48$ and $72 \mathrm{~h})$ showed a progressive reduction of cells in phases G2/M and S with time, whereas the number of cells in phase G0/G1 increased (Figure 2B). Cell culture treatment with HQ1-44, at a concentration close to its $\mathrm{IC}_{50-1}$ value $(2 \mu \mathrm{M})$, led to an arrest of the cell cycle after $72 \mathrm{~h}$ of treatment, resulting in an increase in the percentage of cells in phases G2/M (13.6\% versus $5.0 \%$ in the control), $\mathrm{S}(31.9 \%$ versus $11.3 \%$ in the control) and a drop in those in phase G0/G1 (54.6\% versus $83.6 \%$ in the control). No significant apoptosis was detected by the flow cytometry analysis at this HQ1-44 concentration.

Under the same conditions, these data were confirmed by in situ analyses of the size and shape of cell nuclei after DNA staining, showing the drop in the percentage of viable cells with a small nucleus (G0/G1 phase) and the relative increase in the percentage of cells with a 50\% bigger nucleus, characteristic of cells in $\mathrm{G} 2 / \mathrm{M}$ (Figure 3C). 
For concentrations lower than $5 \mu \mathrm{M}$ that are cytostatic but not cytotoxic, HQ1-44 was ineffective at inducing caspase 3/7 activity (Figure 2C), an early apoptosis marker, while for cytotoxic concentrations

(e.g. up to $5 \mu \mathrm{M})$ HQ1-44 triggered a slight, but significant, increase in caspase $3 / 7(+10 \%)$. The $20 \%$ increase in caspase 3/7 induced by $10 \mu \mathrm{M}$ HQ1-44 remained lower than the effect of $50 \mu \mathrm{M}$ hydrogen peroxide, used as a reference apoptosis inducer $(+45 \%)$.

At sub-toxic HQ1-44 concentrations $(<5 \mu \mathrm{M})$, an in situ analysis of nuclei after DNA staining showed no significant DNA fragmentation, which could reflect apoptosis (Figure 3A), thus supporting the caspase 3/7 activity data. In contrast, some fragmented nuclei were observed after HQ1-44 treatment with cytotoxic concentrations $(10 \mu \mathrm{M}$, Figure $3 \mathrm{~B})$.

\section{3- HQ1-44 affects iron and polyamine metabolisms in HCT116 cells}

Treatment with $20 \mu \mathrm{M}$ iron-citrate induced a marked increase in the level of the L-ferritin protein subunit, and a decrease in the soluble transferrin receptor form in cell supernatants (Figure 4A). In contrast, treatment with the reference iron chelator, ICL670, at a concentration close to its $\mathrm{IC}_{50}(8 \mu \mathrm{M}$, data not shown) caused an iron deficiency characterized by a reduction in the L-ferritin level and an increase in the level of the soluble transferrin receptor, also observed to a lesser extent at $2 \mu \mathrm{M}$ (Figure $4 \mathrm{~A}$ ). At this concentration, HQ1-44 induced a larger reduction in the ferritin level and a greater increase in the level of soluble transferrin receptor 1 than ICL670, confirming a situation of iron deficiency.

Finally, an analysis of the TFRc mRNA, encoding the transferrin receptor 1 protein, showed a downregulation of the expression of this gene in iron overload conditions (20 $\mu \mathrm{M}$ iron-citrate) while an upregulation was observed in iron depletion conditions induced by both chelators, ICL670 and HQ1-44, at 2 $\mu \mathrm{M}$ (Figure 4B).

Polyamine metabolism was also affected by HQ1-44. The addition of $2 \mu \mathrm{M}$ of HQ1-44 to the HCT116 cell culture medium induced a significant reduction in intracellular levels of putrescine and spermidine while the spermine level remained unchanged (Figure 4C). In the same way, a reduction in the level of acetylated spermine (ASpm) was found but with no effect on the acetylated spermidine level (data not shown). Under the same experimental conditions, ICL670 remained ineffective at modulating the polyamine level within HCT116 cells whereas it induced an inhibition of polyamine metabolism in rat and human hepatoma cells 
at higher concentrations [9]. These data suggest that HQ1-44 may induce a disturbance both in the polyamine biosynthetic pathway, by inhibiting the synthesis of putrescine and spermidine, and in their

retro-conversion, by inhibiting the level of acetylated spermidine (Fig. 4C). Analysis of the mRNA levels of genes involved in polyamine biosynthesis, including ornithine decarboxylase (ODC), antizyme (OAZ1), S-adenosylmethionine decarboxylase (SamDC) and polyamine oxidase (PAO), showed a significant downregulation of their expression (Figure 4D).

\section{4- HQ1-44 inhibits tumor growth in vivo}

To test the antiproliferative efficiency of HQ1-44 in vivo, we treated HCT116 xenografted athymic nude mice by i.p. injection with increasing doses of Quilamine (Figure 5, Table 2). After a treatment of 15 days, analysis of the tumor weights showed a non-significant reduction for doses of 6.6 and $20 \mathrm{mg} / \mathrm{kg}$ and a significant reduction for the dose of $40 \mathrm{mg} / \mathrm{kg}(-38 \%)$. Under the same conditions, cis-platin (4 mg/kg) induced a reduction of $29 \%$ of the tumor weight. As expected, the treatment with cis-platin also involved a marked reduction in the weight of the animal's body, liver and spleen $(-17 \%,-17 \%$ and $-44 \%$, respectively) highlighting the toxicity of this compound. Histological analysis of the spleen (Figure 6) showed that the $44 \%$ drop in spleen weight in animals treated with cis-platin was mainly due to a decrease in the red pulp of this organ ( $36 \%$ decrease with respect to the control), as suggested by its paler red color. It is noteworthy that cis-platin administration also induced a behavioral change and reduced activity in mice, while no such changes were observed in Quilamine-treated mice.

By contrast, treatment with the efficient dose of HQ1-44 (40 mg/kg) did not affect the animal and organ weights, or behavior, thus suggesting a better tolerance of the Quilamine at this concentration.

Investigating the impact of HQ1-44 on different iron and polyamine parameters, we found that at doses of 6.6 and $20 \mathrm{mg} / \mathrm{kg}$, the Quilamine did not significantly affect the plasmatic iron concentrations, whereas a significant decrease in iron level was observed for a dose of $40 \mathrm{mg} / \mathrm{kg}(-21 \%)$ (Table 2). By contrast, cisplatin had no effect on iron parameters. Finally, neither treatment (HQ1-44 and cis-platin) affected the intraerythrocytic concentration of polyamines.

\section{5- Polyamine deprivation increases the inhibitory effect of HQ1-44 on tumor growth}


As the in vitro data suggested an additive impact of DFMO with Quilamine, we investigated whether PTS activation might potentialize the Quilamine impact in our mouse model. Thus, polyamine deprivation was

carried out by combining a blockade of endogenous sources, inhibition of intracellular polyamine biosynthesis with DFMO [37] and/or a reduction in exogenous sources by nutritional deficiency in polyamine with a polyamine deficient chow (PDC) [32, 38]. As shown in Table 3, DFMO treatment alone, associated to a nutritional deficiency in polyamine (PDC) or not (PA), inhibits tumor growth, leading to a $33 \%$ and 35\% tumor growth inhibition for PA and PDC animal groups, respectively. Our results showed that polyamine deprivation was efficient in reducing tumor development. The monitoring of tumor size under the different treatments is summarized in Figure 7. After 15 days of treatment, tumour reduction induced by HQ1-44 (-30\%) was amplified in the group receiving 3\% DFMO in their drinking water (56\%). Polyamine deprivation in the group of animals receiving the PDC, in the absence of any other treatment, had no impact on tumor growth while the PDC diet increased the tumor growth inhibitory effect of the combined treatment with HQ1-44 and DFMO (-65\% of tumor growth inhibition). The various treatments did not significantly modify the animal and organ weights, except for DFMO associated with HQ1-44 treatment, which induced a significant reduction in the spleen weights (Table 3). The decrease in spleen weight in animals receiving this combined treatment is low $(-16 \%$ with respect to the control, Table 3) compared to the spleen toxicity of the treatment with $4 \mathrm{mg} / \mathrm{kg}$ cis-platin (-44\%, Table 2$)$. Contrary to the treatment by this alkylating agent, the histological analysis of the spleen after the combined treatment with PDC, DFMO and HQ1-44 did not show any significant decrease in the red pulp of this organ.

A significant decrease in circulating iron in serum was observed in the group of animals receving the Quilamine in conjunction with the polyamine-free diet (Table 4). No change in the ferritin and transferrin levels was detected in these groups while an unexpected decrease in the serum ferritin level was observed in the group of untreated animals receving the polyamine-free diet (PDC). The various treatments did not modify the polyamine levels in RBC (Table 4).

\section{4- Discussion}


Our objective was to investigate whether the vectorized iron chelator HQ1-44 might be of value in the treatment of cancer. Our data demonstrate in vivo that HQ1-44 is effective, by limiting tumor growth of HCT116

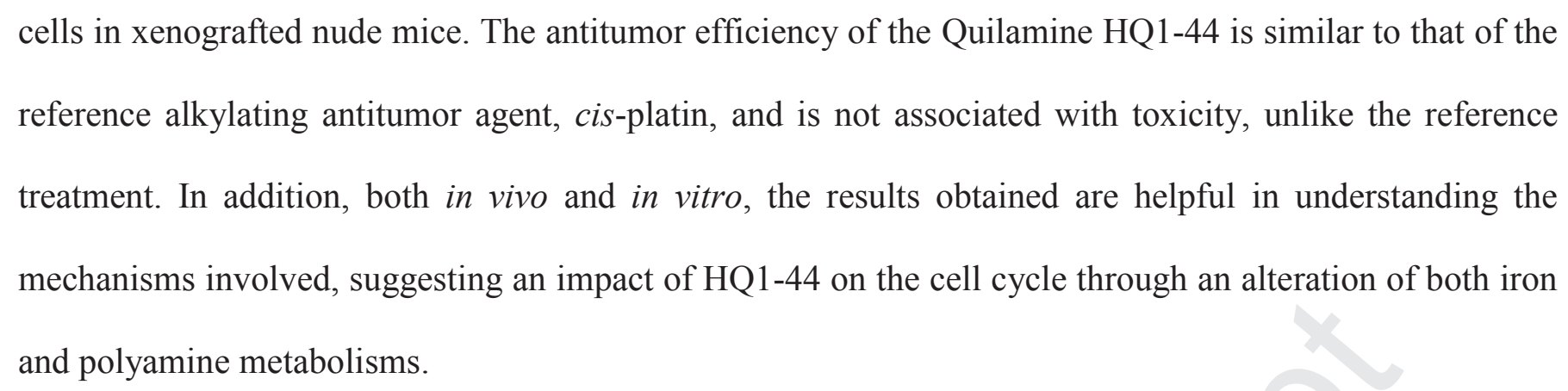

The decrease in the intracellular ferritin protein level and the increase in soluble transferrin receptor concentration in culture medium in the presence of HQ1-44 clearly show that HQ1-44 induces a reduction in the intracellular iron pool in tumor cells, which in turn regulates the expression of these two genes through the Iron Responsive Element/Iron Regulatory Protein (IRE/IRP) system. These data are in accordance with those we previously reported, demonstrating the iron-chelating activity of Quilamines, including HQ1-44. In HQ1-44, the iron-chelating activity of the chelating motif is reinforced by the polyamine backbone, with both the 8 -HQ moiety and the polyamine part participating in the iron coordination [29]. In addition, a role of the amino groups of polyamines in the chelation of metallic cations and in the stability of iron chelates has previously been reported [39, 40]. Such a high capacity for chelating iron is likely to participate in the strong antiproliferative activity, as demonstrated in a previous study, showing that the higher antiproliferative activity of the bis-8-hydroxyquinoline benzylamine chelator S1 in hepatocytes, compared to the iron chelator o-Trensox, was closely connected to the high iron-chelating capacity of this tetradentate ligand [41]. For low concentrations of chelating agents $(2 \mu \mathrm{M})$, the higher iron-chelating capacity of Quilamine HQ1-44, compared to deferasirox, may explain the stronger impact on L-ferritin and transferrin receptor levels, through the IRE/IRP system.

It is noteworthy that in vivo data showing that the serum iron level is only slightly affected with the highest HQ1-44 dose, without a significant change in both systemic ferritin and soluble transferrin receptor levels, support the concept that HQ1-44 is an iron chelator targeting tumoral cells. As reported above, such a concept has been proposed to target other molecules. Our in vivo data, with a low level of side effects, reinforce those obtained in vitro showing the higher sensitivity of proliferating HCT116 cells compared to 
confluent cells, as well as those previously reported, showing that cells not expressing the PTS are less sensitive to HQ1-44 [29]. In addition, the HQ1-44 targeting can be reinforced through polyamine

metabolism manipulation using polyamine depletion tools by providing animals with a polyaminedeficient diet and DFMO, an inhibitor of polyamine biosynthesis, in their drinking water. The polyamine depletion induced by these experimental conditions are currently believed to activate the PTS in tumor cells, as a feedback regulation to maintain the higher polyamine levels required for tumor growth [42].

In addition to its impact on intracellular iron metabolism, HQ1-44 could also exert its antiproliferative activity by modulating polyamine metabolism. Indeed, polyamines are involved in the control of cell cycle progression and cell proliferation [11]. Thus, the ubiquitous polyamine molecules modulate the G1/S transition phase [11]. Our results show that the Quilamine HQ1-44, like deferasirox at higher concentrations, disturbs the metabolism of natural polyamines by inhibiting their biosynthetic pathway. HQ1-44 reduces the gene expression of the metabolism of polyamines, such as those of ornithine decarboxylase (ODC), antizyme (OAZ1) and S-adenosylmethionine decarboxylase (SamDC). This leads to a significant decrease in putrescine, spermidine and a slight, non-significant, reduction in spermine. Such findings are characteristic of a biosynthetic pathway inhibition, such as that of ODC by DFMO. HQ1-44 also modulates the retro-conversion oxidative pathway of polyamines, causing inhibition of the production of N1-acetyl spermine and increased levels of N1-acetyl spermidine. The contribution of the inhibitory effect of chelating iron, such as by Quilamine HQ1-44, to the metabolism of polyamines and their impact on cell proliferation is under study.

In conclusion, HQ1-44 Quilamine is effective in inhibiting HCT116 in vitro and in vivo in xenografted mice. This effect is related to the iron chelator impact of the iron chelator motif, which is reinforced by the polyamine backbone. An inhibitory impact of HQ1-44 on polyamine metabolism may also play a role by affecting cell cycle progression. The polyamine backbone of the molecule enables tumor cells to be targeted and limits the toxicity and side effects of the molecule. Taken together, these results suggest that Quilamines are a way of exploring and adding to the cancer therapeutic panoply in association with other treatments. 


\section{5- Acknowledgments}

This work was supported by the development funds Ouest-Valorisation and FEDER Europe (Brittany

region). The authors are grateful to the Conseil Régional Pays de la Loire, to the French Ministry of Education, to the Ligue Nationale contre le Cancer (LNCC, Ille et Vilaine/Loire Atlantique), to the Association pour la Recherche sur le Cancer (ARC) and to the Centre National de la Recherche Scientifique (CNRS) for financial support.

The authors thank P. Loyer (Inserm UMR991, Rennes, France) and I. Morel (CHU Pontchaillou, Rennes, France) for scientific assistance in the flow cytometry and LC/MSMS analyses, respectively.

In vivo experiments were carried out in the animal handling facility of the university, the ARCHE platform of the Structure Fédérative de Recherche BIOSIT in Rennes (BiogenOuest and Cancéropôle Grand Ouest network).

The histological analysis were carried out in the histopathological platform H2P2 of the Structure Fédérative de Recherche BIOSIT in Rennes (BiogenOuest and Cancéropôle Grand Ouest network).

\section{6- References}

[1] Richardson DR, Kalinowski DS, Lau S, Jansson PJ, Lovejoy DB. Cancer cell iron metabolism and the development of potent iron chelators as anti-tumour agents. Biochim Biophys Acta. 2009;1790:702-17.

[2] Richardson DR. Therapeutic potential of iron chelators in cancer therapy. Adv Exp Med Biol. 2002;509:231-49.

[3] Lane DJ, Mills TM, Shafie NH, Merlot AM, Saleh Moussa R, Kalinowski DS, et al. Expanding horizons in iron chelation and the treatment of cancer: role of iron in the regulation of ER stress and the epithelial-mesenchymal transition. Biochim Biophys Acta. 2014;1845:166-81.

[4] Richardson DR, Ponka P. The molecular mechanisms of the metabolism and transport of iron in normal and neoplastic cells. Biochim Biophys Acta. 1997;1331:1-40.

[5] Kwok JC, Richardson DR. The iron metabolism of neoplastic cells: alterations that facilitate proliferation? Critical reviews in oncology/hematology. 2002;42:65-78.

[6] Brookes MJ, Hughes S, Turner FE, Reynolds G, Sharma N, Ismail T, et al. Modulation of iron transport proteins in human colorectal carcinogenesis. Gut. 2006;55:1449-60.

[7] Torti SV, Torti FM. Iron and cancer: more ore to be mined. Nature reviews Cancer. 2013;13:342-55.

[8] Merlot AM, Kalinowski DS, Richardson DR. Novel chelators for cancer treatment: where are we now? Antioxidants \& redox signaling. 2013;18:973-1006.

[9] Lescoat G, Chantrel-Groussard K, Pasdeloup N, Nick H, Brissot P, Gaboriau F. Antiproliferative and apoptotic effects in rat and human hepatoma cell cultures of the orally active iron chelator ICL670 compared to CP20: a possible relationship with polyamine metabolism. Cell proliferation. 2007;40:755-67. [10] Thomas T, Thomas TJ. Polyamine metabolism and cancer. Journal of cellular and molecular medicine. 2003;7:113-26. 
[11] Wallace HM, Fraser AV, Hughes A. A perspective of polyamine metabolism. Biochem J. 2003;376:114.

[12] Babbar N, Gerner EW. Targeting polyamines and inflammation for cancer prevention. Recent results in cancer research Fortschritte der Krebsforschung Progres dans les recherches sur le cancer. 2011;188:4964.

[13] Annereau JP, Brel V, Dumontet C, Guminski Y, Imbert T, Broussas M, et al. A fluorescent biomarker of the polyamine transport system to select patients with AML for F14512 treatment. Leukemia research. 2010;34:1383-9.

[14] Barret JM, Kruczynski A, Vispe S, Annereau JP, Brel V, Guminski Y, et al. F14512, a potent antitumor agent targeting topoisomerase II vectored into cancer cells via the polyamine transport system. Cancer Res. 2008;68:9845-53.

[15] Bergeron RJ, McManis JS, Franklin AM, Yao H, Weimar WR. Polyamine-iron chelator conjugate. J Med Chem. 2003;46:5478-83.

[16] Bergeron RJ, Singh S, , Bharti N, , Jiang Y. Design, Synthesis, and Testing of Polyamine Vectored Iron Chelators Synthesis. 2010:3631-6.

[17] Bergeron RJ, Wiegand J, McManis JS, Weimar WR, Park JH, Eiler-McManis E, et al. Partitionvariant desferrithiocin analogues: organ targeting and increased iron clearance. J Med Chem. 2005;48:821 31.

[18] Burns MR, Graminski GF, Weeks RS, Chen Y, O'Brien TG. Lipophilic lysine-spermine conjugates are potent polyamine transport inhibitors for use in combination with a polyamine biosynthesis inhibitor. $\mathrm{J}$ Med Chem. 2009;52:1983-93.

[19] Covassin L, Desjardins M, CharestGaudreault R, Audette M, Bonneau MJ, Poulin R. Synthesis of spermidine and norspermidine dimers as high affinity polyamine transport inhibitors. Bioorg Medicinal Chem Letter. 1999;9:1709-14.

[20] Dallavalle S, Giannini G, Alloatti D, Casati A, Marastoni E, Musso L, et al. Synthesis and cytotoxic activity of polyamine analogues of camptothecin. J Med Chem. 2006;49:5177-86.

[21] Delcros JG, Tomasi S, Carrington S, Martin B, Renault J, Blagbrough IS, et al. Effect of spermine conjugation on the cytotoxicity and cellular transport of acridine. J Med Chem. 2002;45:5098-111.

[22] Delcros JG, Vaultier M, Roch NL, Havouis R, Moulinoux JP, Seiler N. Bis(7-amino-4azaheptyl)dimethylsilane: a new tetramine with polyamine-like features. Effects on cell growth. Anticancer Drug design. 1997;12:35-48.

[23] Esteves-Souza A, Lucio KA, Da Cunha AS, Da Cunha Pinto A, Da Silva Lima EL, Camara CA, et al. Antitumoral activity of new polyamine-naphthoquinone conjugates. Oncol Rep. 2008;20:225-31.

[24] Gardner RA, Belting M, Svensson K, Phanstiel IV O. Synthesis and Transfection Efficiencies of New Lipophilic Polyamines. Journal of Medicinal Chemistry. 2007;50:308-18.

[25] Holley J, Mather A, Cullis P, Symons MR, Wardman P, Watt RA, et al. Uptake and cytotoxicity of novel nitroimidazole-polyamine conjugates in Ehrlich ascites tumour cells. Biochem Pharmacol. 1992;43:763-9.

[26] Tomasi S, Renault J, Martin B, Duhieu S, Cerec V, Le Roch M, et al. Targeting the polyamine transport system with benzazepine- and azepine-polyamine conjugates. J Med Chem. 2010;53:7647-63.

[27] Verschoyle RD, Carthew P, Holley JL, Cullis P, Cohen GM. The comparative toxicity of chlorambucil and chlorambucil-spermidine conjugate to BALB/c mice. Cancer Lett. 1994;85:217-22.

[28] Zhuo JC, Cai J, Soloway AH, Barth RF, Adams DM, Ji W, et al. Synthesis and biological evaluation of boron-containing polyamines as potential agents for neutron capture therapy of brian tumors. J Med Chem. 1999;42:1282-92.

[29] Corce V, Morin E, Guiheneuf S, Renault E, Renaud S, Cannie I, et al. Polyaminoquinoline iron chelators for vectorization of antiproliferative agents: design, synthesis, and validation. Bioconjugate chemistry. 2012;23:1952-68.

[30] Corce V, Renaud S, Cannie I, Julienne K, Gouin SG, Loreal O, et al. Synthesis and Biological Properties of Quilamines II, New Iron Chelators with Antiproliferative Activities. Bioconjugate chemistry. 2014;25:320-34.

[31] Rodbard D, McClean SW. Automated computer analysis for enzyme-multiplied immunological techniques. Clinical chemistry. 1977;23:112-5. 
[32] Quemener V, Blanchard Y, Chamaillard L, Havouis R, Cipolla B, Moulinoux JP. Polyamine deprivation: a new tool in cancer treatment. Anticancer Res. 1994;14:443-8.

[33] Gaboriau F, Havouis R, Moulinoux JP, Delcros JG. Atmospheric pressure chemical ionization-mass spectrometry method to improve the determination of dansylated polyamines. Anal Biochem. 2003;318:212-20.

[34] Seiler N. Use of the dansyl reaction in biochemical analysis. Methods Biochem Anal. 1970;18:259337.

[35] Ducros V, Ruffieux D, Belva-Besnet H, de Fraipont F, Berger F, Favier A. Determination of dansylated polyamines in red blood cells by liquid chromatography-tandem mass spectrometry. Anal Biochem. 2009;390:46-51.

[36] Lescoat G, Gouffier L, Cannie I, Lowe O, Morel I, Lepage S, et al. Involvement of polyamines in iron(III) transport in human intestinal Caco-2 cell lines. Molecular and cellular biochemistry. 2013;378:205-15.

[37] Heston WDW, Kadmon D, Covey DF, Fair WR. Differential effect of $\alpha$-difluorométhylornithine on the in vivo uptake of ${ }^{14} \mathrm{C}$-labeled polyamines and méthylglyoxal bis(guanylhydrazone) by a rat prostatederived tumor. Cancer Res. 1984;44:1034-40.

[38] Quemener V, Moulinoux JP, Havouis R, Seiler N. Polyamine deprivation enhances antitumoral efficacy of chemotherapy. Anticancer Res. 1992;12:1447-53.

[39] Løvaas E. Antioxidative and metal-chelating effects of polyamines. In: Sies H, editor. Antioxidants in disease mechanisms and therapy: Academic Press; 1997. p. 116-49.

[40] Palmer BN, Powell HKJ. Polyamine complexes with seven-membered chelate rings: Complexe formation of 3-azaheptane-1,7-diamine, 4-azaoctane-1,8-diamine (spermidine), and 4,9-diazadodecane1,12-diamine (spermine) with copper(II) and hydrogen ions in aqueous solution. JCS Dalton. 1974:208992.

[41] Lescoat G, Leonce S, Pierre A, Gouffier L, Gaboriau F. Antiproliferative and iron chelating efficiency of the new bis-8-hydroxyquinoline benzylamine chelator S1 in hepatocyte cultures. Chem Biol Interact. 2011;195:165-72.

[42] Moulinoux JP, Quemener V, Delcros JG, Cipolla B. Circulating polyamines as biological markers for cancer. In: Nishioka K, editor. Polyamines in cancer : Basic mechanisms and clinical approaches. Austin: Landes Company; 1996. p. 233-50.

\section{7- Legends of tables and figures}

Table 1: Primer sequences.

Table 2: Comparison of the antitumor efficiency of Quilamine HQ1-44 and cis-platin in HCT116 xenografted immunocompromised nude mice. Effect on animal, organ and tumor weights and on blood levels of iron and polyamine parameters. Results from each animal group were expressed as means $\pm \mathrm{SD}$ from three independent measurements. Statistical analysis was performed using the non-parametric MannWhitney test $(* \mathrm{p} \leq 0.05, * * \mathrm{p} \leq 0.01)$.

Table 3: Effect of polyamine depletion on the antitumor efficiency of HQ1-44 in HCT116 xenografted immunocompromised nude mice. Effect on animal, organ and tumor weights. Results from each animal 
group were expressed as means \pm SD from three independent measurements. Statistical analysis was performed using the non-parametric Mann-Whitney test $(* \mathrm{p} \leq 0.05, * * \mathrm{p} \leq 0.01)$.

Table 4: Effect of polyamine depletion on the antitumor efficiency of HQ1-44 in HCT116 xenografted immunocompromised nude mice. Effect on blood levels of iron and polyamine parameters. Results from each animal group were expressed as means \pm SD from three independent measurements. Statistical analysis was performed using the non-parametric Mann-Whitney test $\left(* \mathrm{p} \leq 0.05,{ }^{* *} \mathrm{p} \leq 0.01\right)$.

Figure 1: Relationship between PTS efficiency and the antiproliferative effect of HQ1-44 in HCT116 cell cultures.

A- The effect on cell viability was determined in proliferating cells (treatment at day 1, D1) and in confluent cells $(--$, treatment at day 8 , D8) by measuring DNA content after Hoescht staining and fluorescence analysis. Dose-effect curves of Quilamine HQ1-44 (- --$)$, in the presence of DFMO (2 $\mathrm{mM})\left(-\triangle^{-}\right)$and spermidine $(50 \mu \mathrm{M})\left(-\mathbf{\Delta}^{--}\right)$in proliferating HCT116 cells.

B- Cytotoxic effects of HQ1-44 in proliferating $(-\diamond-$ ' treatment at day 1, D1) and confluent HCT116 cells (- - treatment at day 8, D8). Membrane damage was deduced from lactate dehydrogenase activity in cell supernatants, collected after $72 \mathrm{~h}$ of incubation.

C- Effect of activation ( $2 \mathrm{mM}$ DFMO) or inhibition (exogenous spermidine $50 \mu \mathrm{M}$ ) of the PTS uptake of Quilamine HQ1-44 $(1 \mu \mathrm{M})$ in proliferating (grey bars) and confluent HCT116 cultured cells (black bars). Results were expressed as means \pm SD from three independent measurements. * means $\mathrm{p} \leq 0.01$ between treated and control cells.

Figure 2: Effect of HQ1-44 on DNA synthesis, cell cycle and apoptosis in proliferating HCT116 cultured cells.

(A) Effect of HQ1-44 (2 $\mu \mathrm{M})$ on DNA synthesis measured by ${ }^{3} \mathrm{H}$-thymidine uptake (24 h incorporation). (white bars, untreated control cells; grey bars, cells treated with $2 \mu \mathrm{M}$ HQ1-44) 
(B) Effect of HQ1-44 $(2 \mu \mathrm{M})$ on the cell cycle analyzed by FACS after propidium iodide staining. The percentage of cells in each phase of the cell cycle was deduced by using Cell Quest software. White bars;

G0/G1 phase; grey bars; S phase, black bars; G2/M phase

(C) Effect of HQ1-44 on apoptosis analyzed by measuring caspase 3/7 activity. $50 \mu \mathrm{M}$ hydrogen peroxide treatment was used as a reference apoptosis inducer.

Figure 3: Effect of HQ1-44 on cell nuclei of HCT116 cells (shape and size). The impact of HQ1-44 was analyzed by Hoescht staining. (A) Morphology of nuclei of HCT116 cells treated with $2 \mu \mathrm{M}$ HQ1-44 for 72h. (B) Morphology of nuclei of HCT116 cells treated with $10 \mu \mathrm{M}$ HQ1-44 for $72 \mathrm{~h}$ Fragmented nuclei $(\mathrm{FN})$.

(C) Analysis of the mean size of nuclei of HCT116 cells treated with increasing concentrations of HQ1-44 for $72 \mathrm{~h}$.

Figure 4: Effect of a $72 \mathrm{~h}$ treatment of proliferating HCT116 cells with HQ1-44 (2 $\mu \mathrm{M})$, ICL670 $(2 \mu \mathrm{M})$ and iron-citrate $(20 \mu \mathrm{M})$ on iron (A and $\mathrm{B})$ and polyamine (C and D) metabolisms. The effect on both iron and polyamine metabolisms of the reference chelator ICL670 ( $2 \mu \mathrm{M}$ deferasirox $)$, which was previously shown to induce an iron deficiency, was compared to that of $2 \mu \mathrm{M} \mathrm{HQ1-44}$ and to $20 \mu \mathrm{M}$ iron-citrate (mimicking the situation of iron overload).

A- The soluble transferrin receptor1 (white histogram, $\square$ ) in cell supernatants and the intracellular ferritin level (black histogram, $\boldsymbol{\square}$ ) were measured in proliferating HCT116 cells after 72 hours of treatment with the various iron effectors. These two parameters were corrected from total protein concentrations.

B- Gene expression of the transferrin receptor1 (white histogram, $\square$ ) and ferritin (black histogram, was analyzed by RT-qPCR in proliferating HCT116 cells after $72 \mathrm{~h}$ of treatment.

C- Intracellular polyamine levels (putrescine, $\square$; spermidine, $\square$; spermine, $\square$ and N1-acetyl spermine, - ) after treatment with the various iron effectors. These two parameters were corrected from total protein concentrations.

D- Gene expression of ornithine decarboxylase ( $\square$, ODC), antizyme ( $\square$, OAZ1), S-adenosylmethionine decarboxylase ( $\square$, SamDC) and polyamine oxidase ( $\boldsymbol{\square}$, PAO), which were analyzed by RT-qPCR.

* significant differences according to the Mann-Whitney test $(\mathrm{p}<0.01)$. 
Figure 5: Antitumor effect of HQ1-44 compared to cis-platin in HCT116 xenografted athymic nude mice. Tumor weight after 15 days intraperitoneal administration of Quilamine (0 to $40 \mathrm{mg} / \mathrm{kg}$ ) and cis-platin (4 $1 \mathrm{mg} / \mathrm{kg}) .{ }^{*} \mathrm{p}<0.01$.

Figure 6: Histological analysis of spleen. Hematoxyline eosine saffron (HES) staining from HCT116xenografted nude animals (A) untreated animals, (B) mice treated by the intraperitoneal route for a couple of weeks with $40 \mathrm{mg} / \mathrm{kg} \mathrm{HQ1-44} \mathrm{(B),} \mathrm{and} \mathrm{(C)} \mathrm{mice} \mathrm{treated} \mathrm{by} 4 \mathrm{mg} / \mathrm{kg}$ cis-platin (C). Red pulp (RP), White pulp (WP), Trabecule (T) and germinative center (GC) structures are indicated by arrows.

Figure 7: Effect of polyamine depletion induced by DFMO and/or by a polyamine-deficient diet (PDC) on the antitumor effect of the Quilamine HQ1-44 in HCT116 xenografted immunocompromised nude mice. Tumor growth curves in animals treated with polyamine containing diet (PA, - - - - ), polyamine deficient chow (PDC, - - ), PA and 40mg/kg HQ1-44 (-- --), PDC and $40 \mathrm{mg} / \mathrm{kg}$ HQ1-44 (-口-),

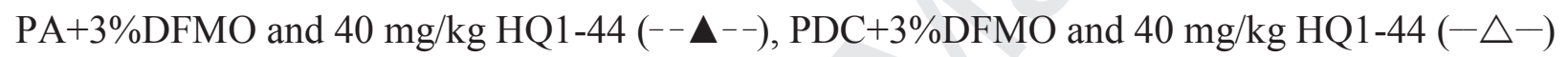




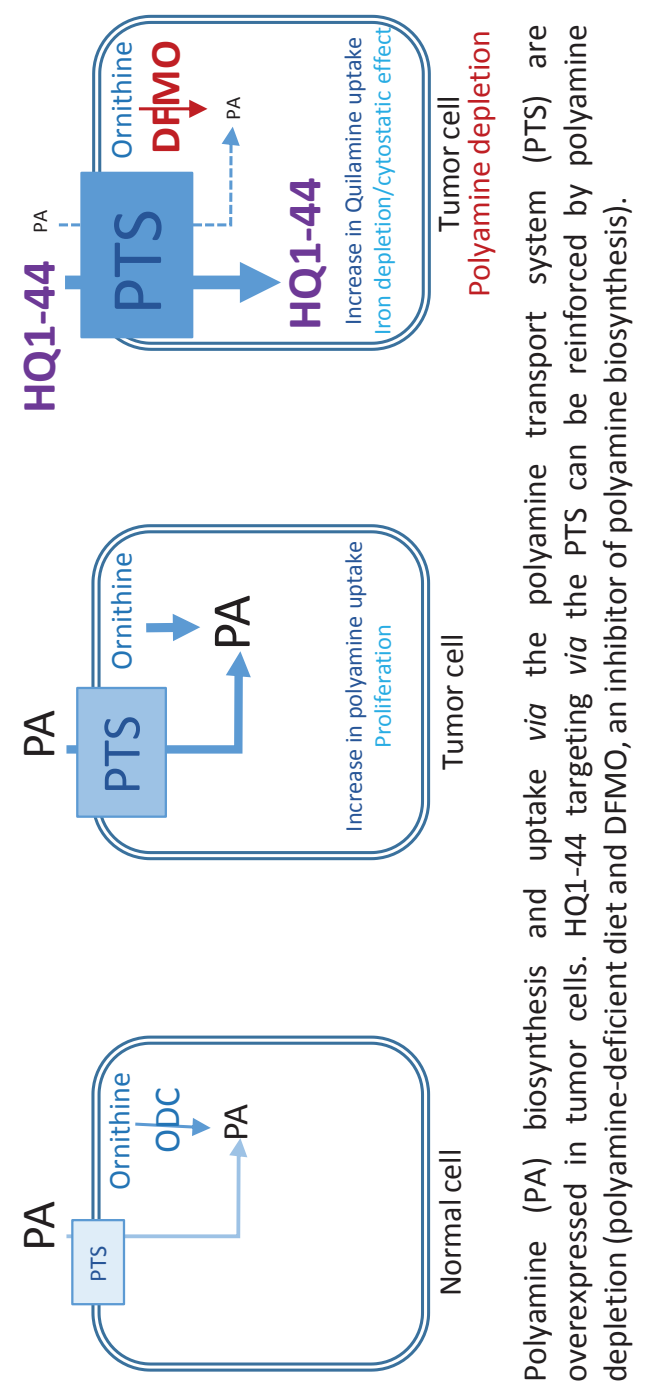


18S : $\quad$ Rev: 5'-TCGAGGCCCTGTAATTGGAA-3'

Fw : 5'-CCCAAGATCCAACTACGAGCTTT-3'

TfR1 : $\quad$ Rev : 5'-GCTTTCCCTTTCCTTGCATATTCT-3'

Fw : 5'-GTGGTACCCAAATAAGGATAATCTGT-3'

L-ferritine : Rev : 5'-AGGGCCCCTTGCAAATTAA-3'

Fw : 5'-GCCTATTGGCTGGAGGGAG-3'

PAO: Rev: 5'-GGTAGGCTGGGACCGTCATT-3'

FW : 5'-AAGGTGGCCCTGGTTACCA-3'

OAZ1 : $\quad$ Rev: 5'-AATTCCGCCGAAAAAGAGAAG-3'

Fw ; 5'-CTCCTAGGCCCTCTGGGTAGTT-3'

SAMDC : Rev : 5'-TCGTCTTCCGCAGTAAGACCTAT-3'

Fw : 5'-CTTTGCAGTAACACCATCTTTGATG-3'

ODC : $\quad$ Rev : 5'-CGGTACAGCCGCTTCCTACA-3'

Fw : 5'-CGGTGCCACGCTCAGAAG-3'

Table 1 


\begin{tabular}{|c|c|c|c|c|c|c|}
\hline & & Control & $\begin{array}{c}\text { HQ1-44 } \\
6.6 \mathrm{mg} / \mathrm{kg}\end{array}$ & $\begin{array}{c}\text { HQ1-44 } \\
20 \mathrm{mg} / \mathrm{kg}\end{array}$ & $\begin{array}{c}\mathrm{HQ1}-44 \\
40 \mathrm{mg} / \mathrm{kg}\end{array}$ & $\begin{array}{c}\text { CisPt } \\
4 \mathrm{mg} / \mathrm{kg}\end{array}$ \\
\hline \multirow{6}{*}{ Organ weight } & Mouse (g) & $24.7 \pm 1.5$ & $23.6 \pm 1.5$ & $25.0 \pm 1.1$ & $24.6 \pm 2.7$ & $20.6 \pm 2.2 * *$ \\
\hline & Tumor (mg) & $619 \pm 143$ & $511 \pm 213$ & $567 \pm 197$ & $381 \pm 45 * *$ & $439 \pm 53 *$ \\
\hline & Spleen (mg) & $129 \pm 20$ & $121 \pm 11$ & $126 \pm 16$ & $142 \pm 27$ & $71 \pm 13 *$ \\
\hline & Kidney (mg) & $353 \pm 27$ & $348 \pm 46$ & $354 \pm 26$ & $381 \pm 50$ & $321 \pm 17$ \\
\hline & Liver (mg) & $1347 \pm 97$ & $1181 \pm 65$ & $1378 \pm 47$ & $1321 \pm 180$ & $1118 \pm 104^{*}$ \\
\hline & Heart (mg) & $117 \pm 15$ & $120 \pm 21$ & $115 \pm 11$ & $128 \pm 17$ & $100 \pm 10$ \\
\hline \multirow{3}{*}{$\begin{array}{c}\text { Iron } \\
\text { parameters }\end{array}$} & Iron $(\mu \mathrm{M})$ & $49 \pm 6.2$ & $45 \pm 6.4$ & $41 \pm 10.5$ & $38.8 \pm 4.2 *$ & $49 \pm 9.8$ \\
\hline & Ferritin $(\mu \mathrm{g} / \mathrm{l})$ & $2161 \pm 423$ & $1775 \pm 453$ & $1692 \pm 562$ & $1949 \pm 545$ & $2746 \pm 1095$ \\
\hline & Transferrin (g/l) & $3.1 \pm 1$ & $3.6 \pm 0.4$ & $4.9 \pm 2.6$ & $6.8 \pm 4.3$ & $5.6 \pm 2.9$ \\
\hline \multirow{3}{*}{$\begin{array}{l}\text { Polyamines } \\
\quad(\mathbf{n M})\end{array}$} & Putrescine & $133 \pm 31$ & $138 \pm 34$ & $102 \pm 23$ & $144 \pm 64$ & $138 \pm 23$ \\
\hline & Spermine & $1044 \pm 203$ & $823 \pm 231$ & $877 \pm 120$ & $1119 \pm 372$ & $1219 \pm 390$ \\
\hline & Spermidine & $5045 \pm 479$ & $3545 \pm 579$ & $6186 \pm 887$ & $5859 \pm 1377$ & $6718 \pm 1677$ \\
\hline
\end{tabular}

Table 2 


\begin{tabular}{|c|c|c|c|c|c|c|}
\hline & Mouse (g) & Tumor (mg) & Spleen (mg) & Kidney (mg) & Liver (mg) & Heart (mg) \\
\hline PA & $25,6 \pm 2$ & $492 \pm 81$ & $120 \pm 11$ & $351 \pm 20$ & $1472 \pm 105$ & $131 \pm 12$ \\
\hline PDC & $27,3 \pm 1,5$ & $428 \pm 107$ & $126 \pm 10$ & $380 \pm 27$ & $1513 \pm 134$ & $122 \pm 5$ \\
\hline PA+DFMO & $26,2 \pm 1,4$ & $328 \pm 108 *$ & $118 \pm 16$ & $390 \pm 21$ & $1550 \pm 98$ & $128 \pm 12$ \\
\hline PDC+DFMO & $25,4 \pm 1,5$ & $276 \pm 78^{*}$ & $127 \pm 21$ & $382 \pm 25$ & $1344 \pm 67$ & $122 \pm 8$ \\
\hline PA+HQ1-44 & $26,1 \pm 1,3$ & $359 \pm 29 *$ & $109 \pm 27$ & $367 \pm 43$ & $1443 \pm 169$ & $117 \pm 7$ \\
\hline PDC+HQ1-44 & $26,1 \pm 1,3$ & $357 \pm 32 *$ & $110 \pm 10$ & $410 \pm 41$ & $1349 \pm 108$ & $116 \pm 7$ \\
\hline PA+HQ1-44+DFMO & $24,4 \pm 1,07$ & $217 \pm 35 * *$ & $99 \pm 12 *$ & $402 \pm 33$ & $1385 \pm 103$ & $117 \pm 8$ \\
\hline PDC+HQ1-44+DFMO & $25,3 \pm 1,9$ & $170 \pm 66 * *$ & $106 \pm 13^{*}$ & $410 \pm 41$ & $1394 \pm 200$ & $120 \pm 10$ \\
\hline
\end{tabular}

Table 3 


\begin{tabular}{|l|c|c|c|c|c|c|}
\cline { 2 - 7 } \multicolumn{1}{c|}{} & \multicolumn{3}{c|}{ Iron Parameter } & \multicolumn{3}{c|}{ Polyamines } \\
\cline { 2 - 7 } \multicolumn{1}{c|}{} & $\begin{array}{c}\text { Iron } \\
(\mu \mathrm{M})\end{array}$ & $\begin{array}{c}\text { Ferritin } \\
(\mu \mathrm{g} / \mathrm{l})\end{array}$ & $\begin{array}{c}\text { Transferrin } \\
(\mathrm{g} / \mathrm{l})\end{array}$ & $\begin{array}{c}\text { Putrescine } \\
(\mu \mathrm{M})\end{array}$ & $\begin{array}{c}\text { Spermine } \\
(\mu \mathrm{M})\end{array}$ & $\begin{array}{c}\text { Spermidine } \\
(\mu \mathrm{M})\end{array}$ \\
\hline PA & $38,30 \pm 4,95$ & $1187 \pm 328$ & $2,46 \pm 0,93$ & $0,24 \pm 0,14$ & $7,73 \pm 3,30$ & $0,48 \pm 0,27$ \\
\hline PDC & $38,37 \pm 5,65$ & $\mathbf{7 6 9} \pm \mathbf{2 2 2} * *$ & $1,79 \pm 0,46$ & $0,18 \pm 0,14$ & $6,24 \pm 1,06$ & $0,35 \pm 0,12$ \\
\hline PA+DFMO & $34,25 \pm 8,44$ & $932 \pm 146$ & $2,48 \pm 1,14$ & $0,22 \pm 0,17$ & $11,04 \pm 4,8$ & $0,73 \pm 0,45$ \\
\hline PDC+DFMO & $33,97 \pm 13,88$ & $33,97 \pm 13,88$ & $1,80 \pm 0,66$ & $0,14 \pm 0,05$ & $8,8 \pm 2,58$ & $0,64 \pm 0,28$ \\
\hline PA+HQ1-44 & $37,00 \pm 9,50$ & $920 \pm 158$ & $2,19 \pm 0,52$ & $0,24 \pm 0,17$ & $5,78 \pm 1,53$ & $0,30 \pm 0,10$ \\
\hline PDC+HQ1-44 & $\mathbf{2 6 , 7 3 \pm 6 , 1 1 * *}$ & $1118 \pm 535$ & $2,05 \pm 0,34$ & $0,19 \pm 0,11$ & $8,58 \pm 4,00$ & $0,69 \pm 0,51$ \\
\hline PA+HQ1-44+DFMO & $38,00 \pm 13,88$ & $1165 \pm 324$ & $1,65 \pm 0,66$ & $0,18 \pm 0,14$ & $7,04 \pm 1,60$ & $0,53 \pm 0,3$ \\
\hline PDC+HQ1-44+DFMO & $\mathbf{2 8 , 9 4 \pm 6 , 6 2 * *}$ & $1098 \pm 146$ & $1,73 \pm 1,12$ & $0,18 \pm 0,11$ & $8,64 \pm 3,47$ & $0,58 \pm 0,25$ \\
\hline
\end{tabular}

Table 4 

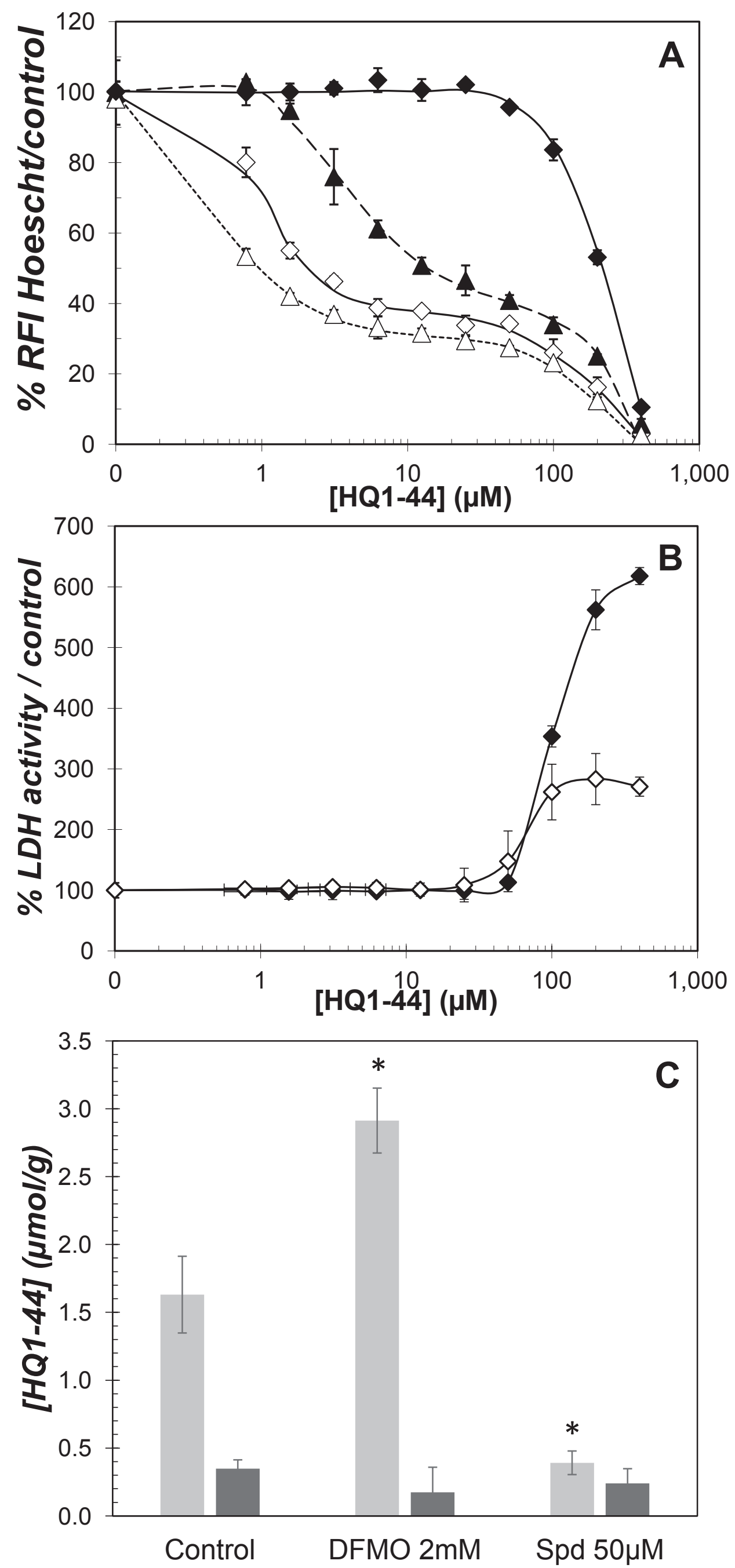

Figure 1 

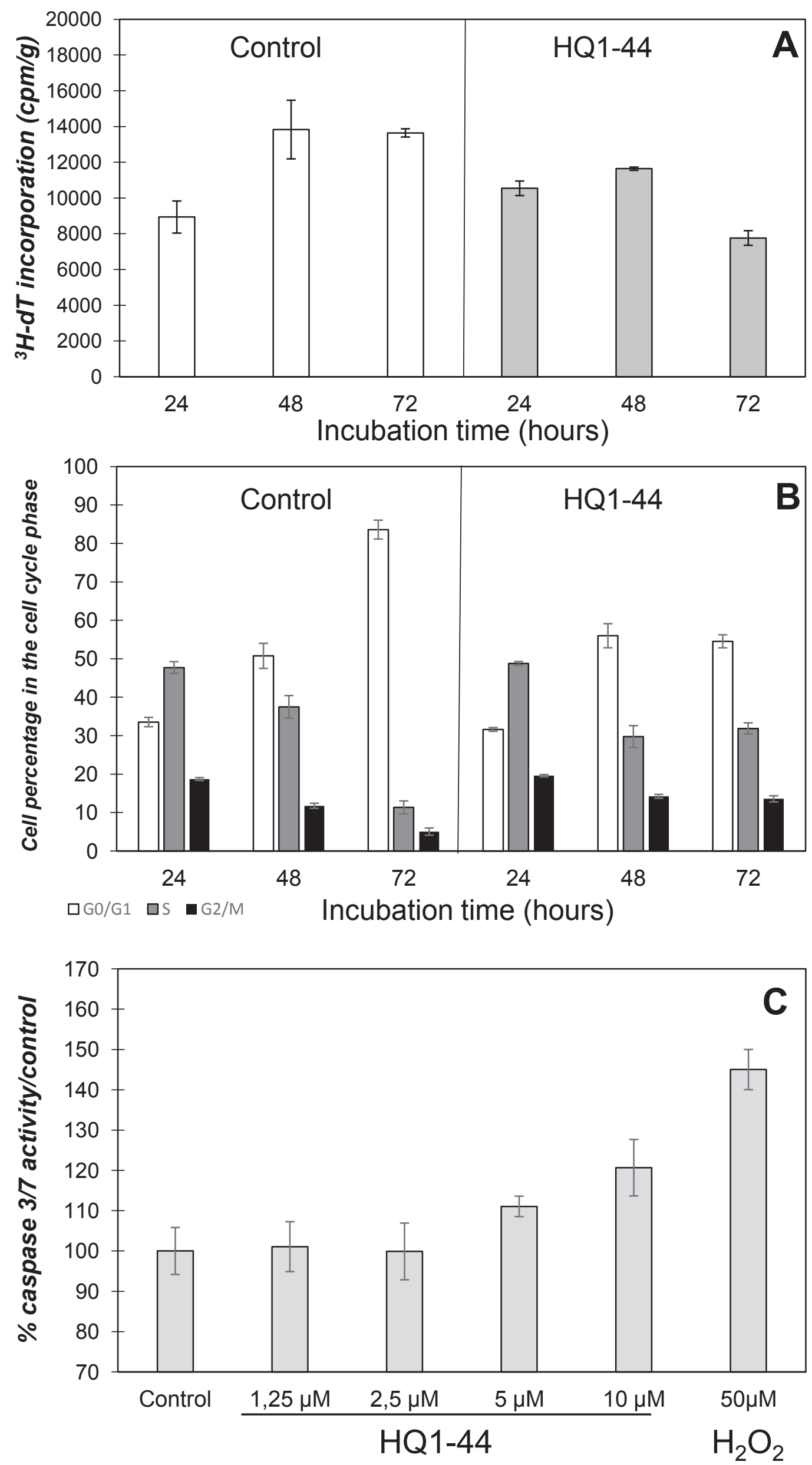

Figure 2 

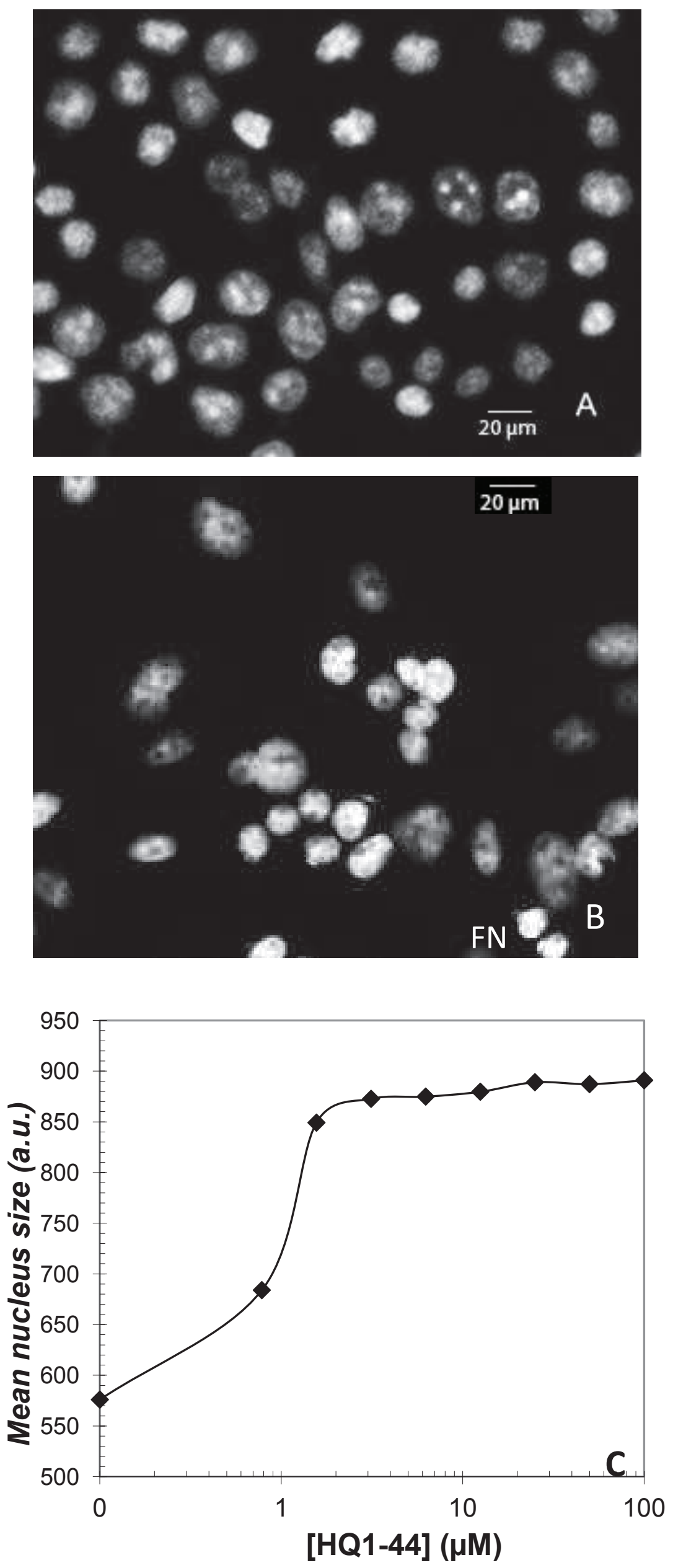

Figure 3 

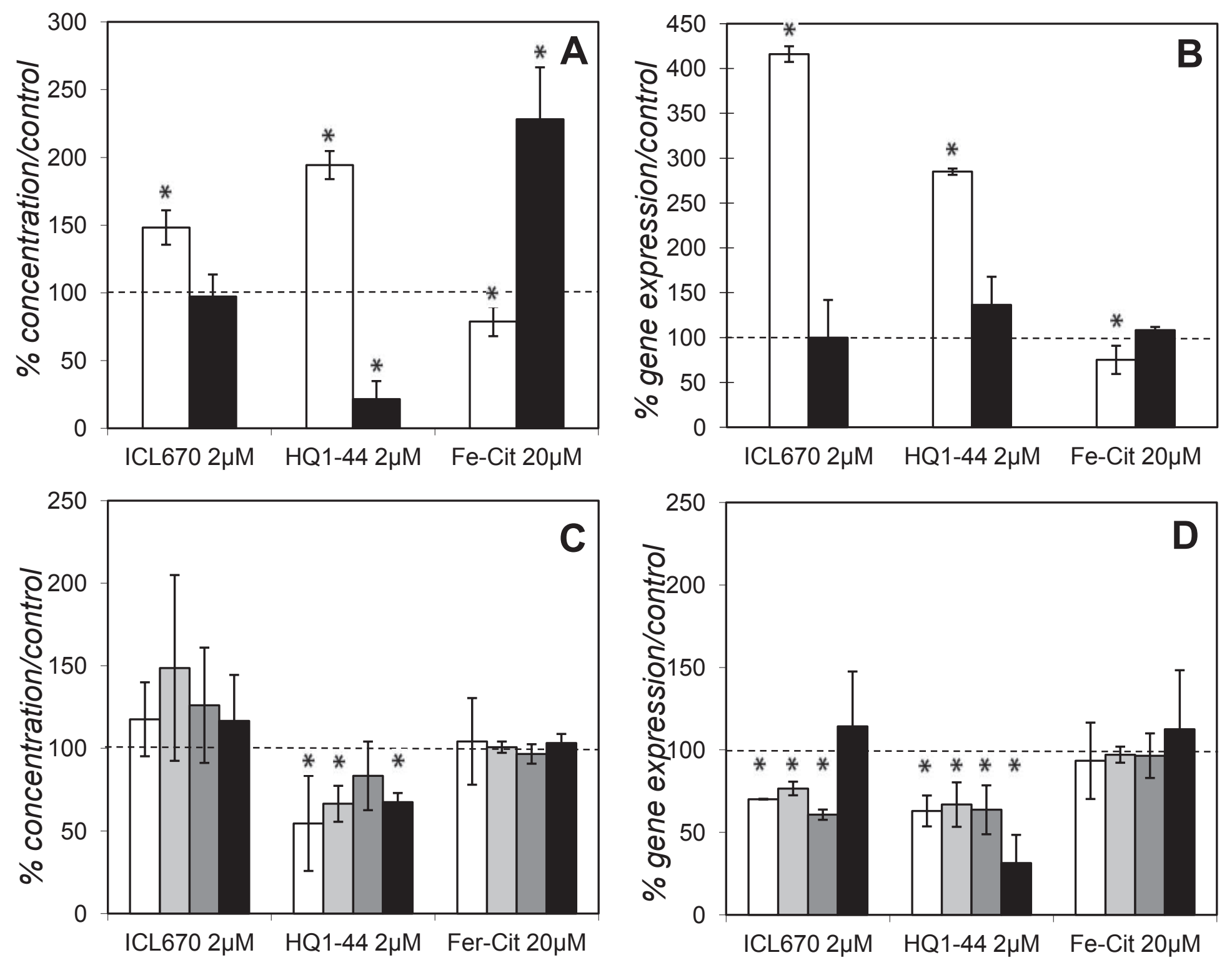

Figure 4 


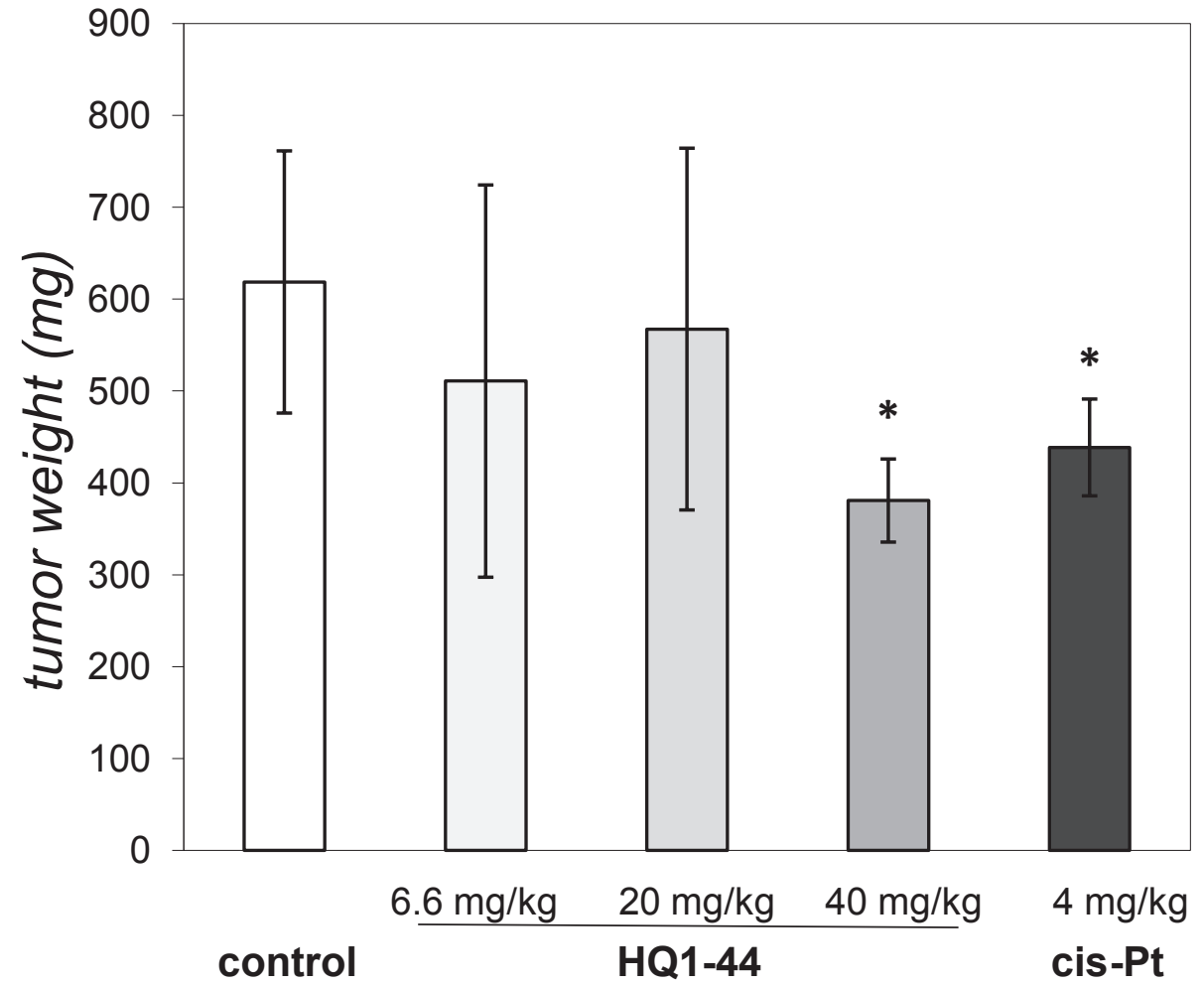

Figure 5 

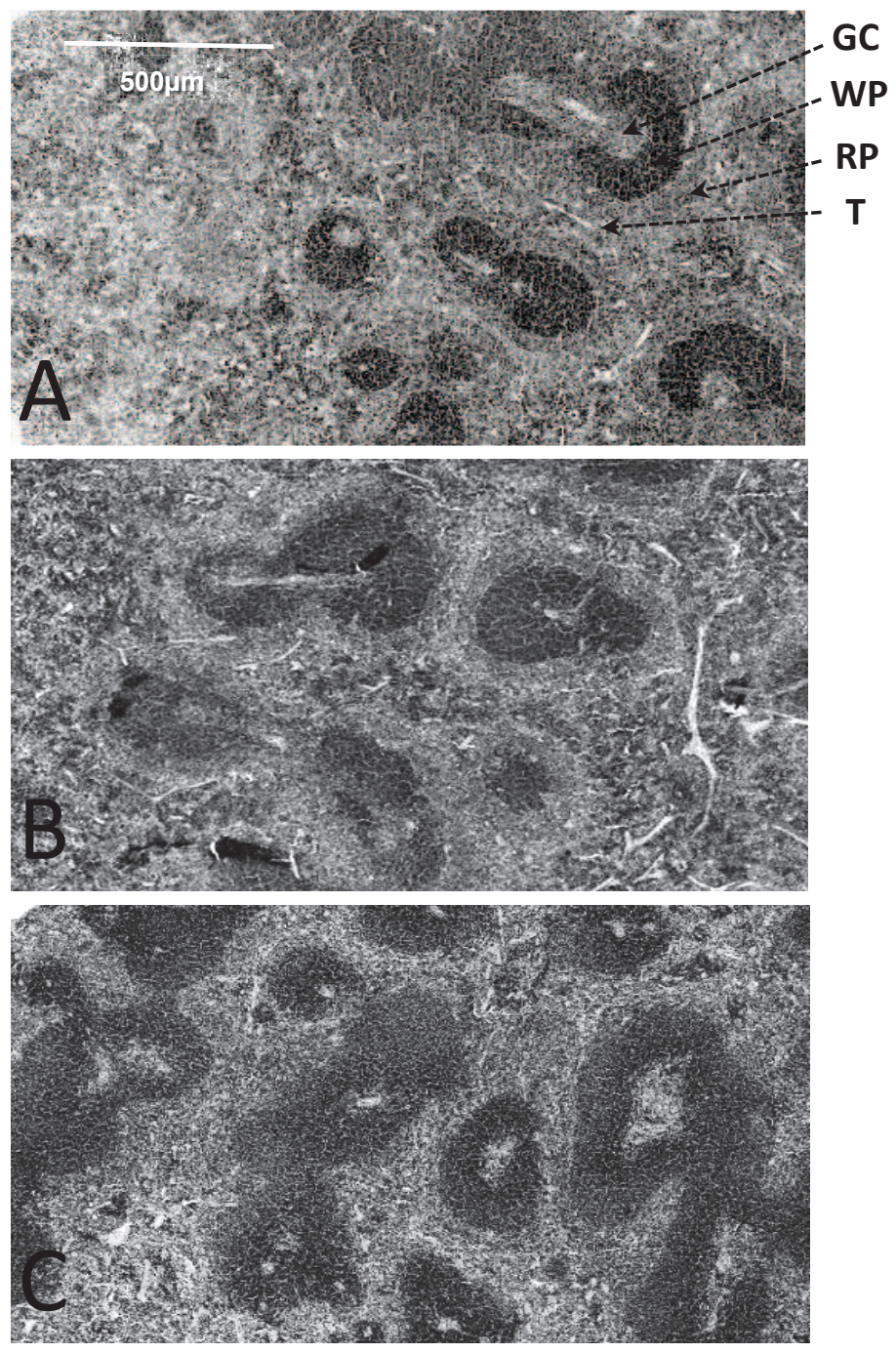

Figure 6 


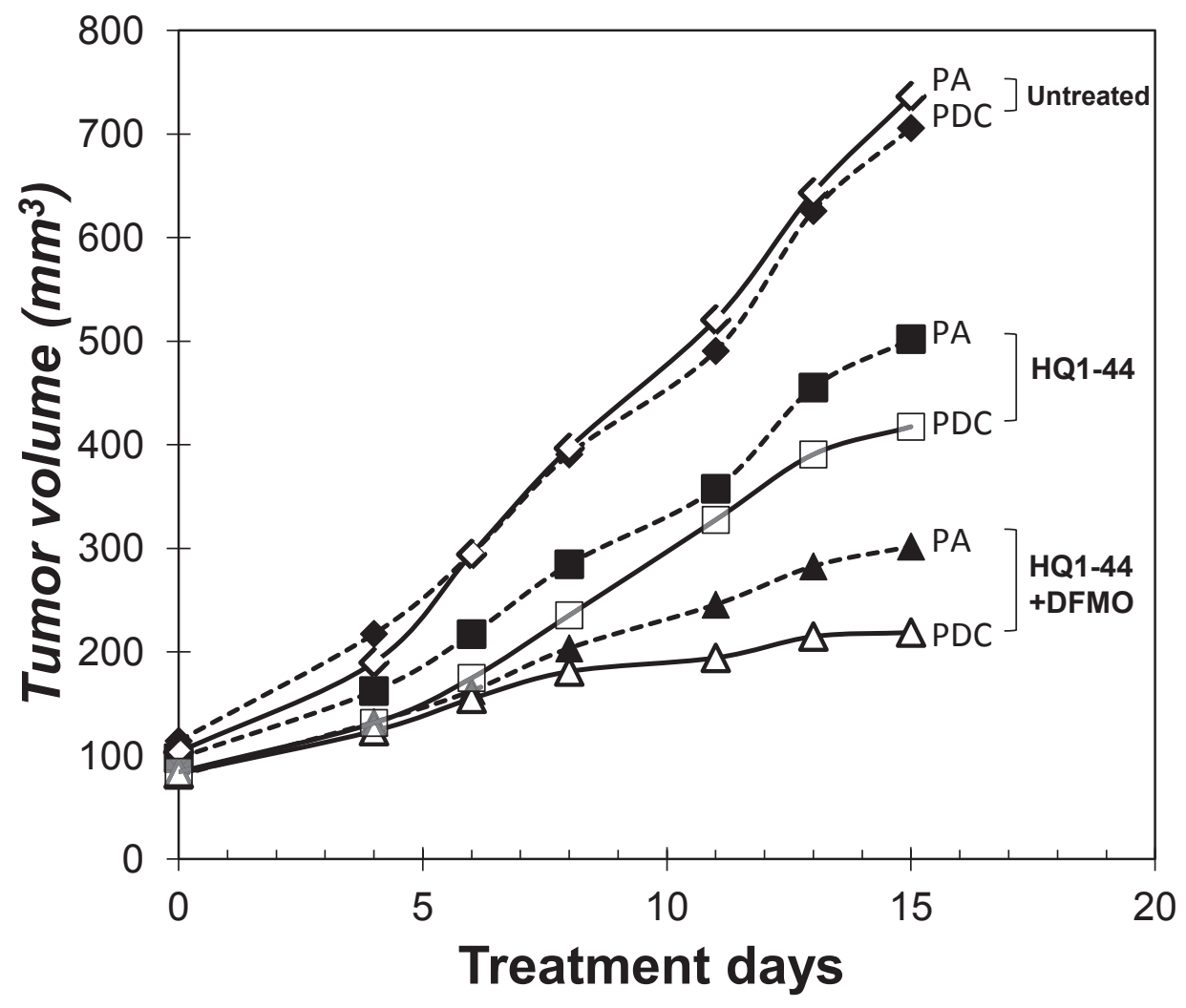

Figure 7 